\title{
Speech Act dalam Headline Berita Media Online
}

\author{
Riris Tiani \\ Fakultas Ilmu Budaya, Universitas Diponegoro \\ tiani.riris@gmail.com
}

\begin{abstract}
The development of pragmatic strategy in the journalistic process has an effect on the image of the person who has been reported. Directly or not, imaging of political figures to public figures is influenced by pragmatic strategies packed with journalists in the news media. Political figures until the public figure collaborate to create an interesting impression. An interesting impression or positive image will change the concept of society over this overnight assessment. The higher the pragmatic power journalists developed in writing the news, the better the quality of the news will be. In accordance with the results of pragmatic strategy research on Headline news on Republika.co.id can be concluded that in the creation of news headlines have implemented pragmatic strategy. The dominant pragmatic strategy used is the illocution act. The illusionary strategy becomes dominant because the news content that is headlined is dominated by political and economic news. So the development of explaination techniques more highlighted.
\end{abstract}

Key word: pragmatic strategy, headline, illocutionary act

\section{Intisari}

Pengembangan strategi pragmatik dalam proses jurnalistik berpengaruh terhadap pencitraan atas tokoh yang diberitakan. Secara langsung atau tidak, pencitraan tokoh politik sampai public figure dipengaruhi oleh strategi pragmatic yang dikemas jurnalis dalam media berita.Tokoh politik sampai public figure saling melakukan kolaborasi untuk menciptakan kesan yang menarik. Kesan menarik atau pencitraan positif akan mengubah konsep masyarakat atas penilaian semalama ini. Semakin tinggi jurnalis daya pragmatic yang dikembangkan jurnalis dalam menulis berita, maka akan semakin baik pula kualitas berita yang diberikan. Sesuai dengan hasil penelitian strategi pragmatik pada Headline berita pada Republika.co.id dapat disimpulkan bahwa dalam penciptaan headline berita sudah menerapkan strategi pragmatik. Strategi pragmatik yang dominan digunakan adalah strategi ilokusi. Strategi ilokusi menjadi dominan karena konten berita yang menjadi headline didominasi dengan berita politik dan ekonomi. Sehingga pengembangan teknik eksplanasi lebih ditonjolkan.

Kata kunci: strategi pragmatik, headline, tindak tutur ilokusi 


\section{Pendahuluan}

Dalam upaya menarik minat pembaca, seorang jurnalis menggunakan strategi pragmatik dengan tujuan menciptakan bahasayang menarik seperti dalamheadline berita. Headline berita merupakan penggambaran dari suatu peristiwa tertentu. Dapat diketahui penting dan tidaknya peristiwa yang terjadi, melaluiheadline juga akan membawa pengaruh bagi para pembacanya.

Banyak dan tidaknya berita itu dibaca sangat bergantung dari strategi pragmatik yang diterapkan oleh jurnalis dalam menciptakan headline. Strategi pragmatik tidak hanya berhenti sampai penciptaan headline saja. Dalam menciptakan narasi beritapun memerlukan strategi pragmatik. Berjalannya waktu, pembaca akan memberikan penilaian tersendiri terkait posisi mediaonline tersebut masuk pada level prestisius dalam hal ini konten berita selalu akurat atau pada level marginal dimana hanya melihat pada efek ekonomi saja.

Dalam usaha untuk mengungkapkan informasi, penutur tidak hanya menghasilkan tuturan yang mengandung kata-kata dan struktur-struktur gramatikal saja, tetapi juga memperlihatkan tindakan-tindakan yang melalui tuturan tersebut (Yule, 1996). Segala tindakan yang dilakukan pada saat berkomunikasi dalam peristiwa tutur dapat dikatakan sebagai tindak tutur. Misalnya, menyatakan, menasehati, menyarankan, dan mengkritik. Setiap tindak tutur melibatkan penutur, lawan tutur, konteks tuturan, dan situasi tutur yang disebut komponen tuturan. Leech (1993) menjelaskan bahwa, tindak tutur adalah unit terkecil aktifitas berbicara yang dapat dikatakan dengan mempertimbangkan relasi antara bahasa dan konteks yang melatarbelakanginya.Tiga jenis tindak tuturtersebut adalah lokusi, ilokusi, dan perlokusi.Tindak tutur lokusi (locutionaryact) adalah tindak tutur yang berhubungan dengan mengatakan sesuatu. Tindak lokusi juga disebut an act of saying something. Tindak tutur ini merupakan tindak tutur yang mengaitkan suatu topik dengan suatu keterangan dalam suatu pernyataan atau ungkapan. Tindak tutur ilokusi (illocutionary acts) adalah tindak tutur yang berisi pengucapan suatu pernyataan, pertanyaan, tawaran, janji, dan lain-lain yang erat berhubungan dengan bentuk - bentuk kalimat. Berkaitan dengan perbuatan dalam hubungannya dengan mengatakan sesuatu. Tindak ilokusi juga disebut an act of doing somethings in saying something.Tindak tutur perlokusi (perlocutionary acts) adalah tindak tutur yang bisa memberikan efek pada 
pendengar sesuai dengan situasi dan kondisi pengucapan tindak tutur. Dengan kata lain, tindak tutur perlokusi dapat menimbulkan akibat, karena adanya suatu tindakan dalam mengatakan sesuatu. Tindak perlokusi mengandung maksud dan efek tertentu pada lawan tutur/pendengar. Tindak perlokusi juga disebut an act some effect because of doing something in saying something.

Berdasarkan uraian di atas, maka penelitian ini berusaha mengungkap strategi pragmatik yang digunakan dalam penciptaan headline di media online. Penelitian ini bertujuan untuk mengidentifikasi dan menjelaskan apasaja dan bagaimana bentuk strategi pragmatik yang digunakan dalam menciptakan citra publik figure atau pejabat publik dalam ranah media.

\section{Metode}

Metode yang digunakan dalam penelitian ini adalah metode simak dengan teknik catat. Metode simak, yakni menyimak data dari website Republika.co.id. Jenis penelitian ini adalah penelitian deskriptif kualitatif. Subjek penelitian dari headline media online Republika.co.id diambil secara purposive.Media Republika digunakan karena mewakili media online yang terbesar dengan jumlah pelanggan media sosial dan berita yang disajiikan berskala nasional, sehingga pengambilan data difokuskan pada media Republika.Tidak semua headline menjadi subjek penelitian karena subjek penelitian harus memiliki kriteria pragmatis tersendiri, dalam penelitian ini sumber berita hanya dipilih sesuai dengan topic-topik pemberitaan tertentu yang berhubungan dengan bidang politik dan ekonomi. Setelah subjek penelitian didapat dan direduksi, maka data akan dianalisis menggunakan kajian pragmatik. Penelitian ini menggunakan teori pragmatik speech act Leech.

\section{Pembahasan}

Sesungguhnya pada saat mengungkapkan gagasannya dengan cara berucap, penutur tidak hanya menghasilkan tuturan berupa kata-kata, namun mereka juga memperlihatkan tindakan-tindakan melalui tuturan tersebut. Hal ini kemudian muncul istilah tindak tutur, yang berarti segala tindakan yang dilakukan pada saat berkomunikai 
dalam suatu peristiwa tutur. Tindakan tersebut dapat berupa mengajurkan, mengkritik, mengajak, memperingatkan, menolak atau meminta.

\section{Tindak Lokusi}

Lokusi atau dengan kata lain the act of saying somethingdapat dimaknai sebagai tindak tutur untuk menyatakan sesuatu. Berikut analisis headline media online yang diduga menggunakan strategi lokusi:

Data (1)Ralat Kenaikan BBM, Pertamina: Tak Ada Tekanan dari Pihak Manapun.

Headline pada data (1)Ralat Kenaikan BBM, Pertamina: Tak Ada Tekanan dari Pihak Manapun tampak sekali menggunakan strategi pragmatik. Strategi pragmatik yang digunakan adalah locutionary act. Strategi ini digunakan untuk membuat memberikan penjelasan kepada pembaca atau khalayak, terkait kenaikan harga BBM sebelumnya yang sempat membuat kekacauan sosial di masyarakat. Maka muncul headline bahwa kenaikan harga BBM tertunda sesungguhnya tidak ada tekanan dari pihak manapun.Jurnalis mencoba mempertegas informasi bahwa tertundanya kenaikan harga BBM tersebut merupakan kekeliruan internal dari pembuat kebijakan pada instansi terkait. Sehingga bias tafsir pada masyarakat teredam atas penjelasan yang riil yang dibuat oleh jurnalis.

\section{Data (2)Menteri ESDM: Kenaikan Pertamax Tiap Dua Pekan Sebetulnya Biasa}

Headline pada data (2) Menteri ESDM: Kenaikan Pertamax Tiap Dua Pekan Sebetulnya Biasa, mengembangkan strategi lokusi, dengan tujuan untuk menyatakan sesuatu. Dalam tuturannya, Menteri ESDM menyampaikan terjadinya kenaikan pertamax setiap dua pekan merupakan kejadian yang biasa. Ada sebuah bias makna bahwa secara logika dampak kenaikan BBM bisa berimplikasi terhadap kenaikan sektor lain. Akibat dari kenaikan harga tersebut, pasti akan menambah beban finansial masyarakat secara menyeluruh.

Pernyataan yang disampaikan menteri ESDM berbanding terbalik dengan fakta yang ada. Menteri berusaha menjelaskan yang tampak pada pemarkah sebetulnya biasa, hal itu dilakukan dengan tujuan untuk memberikan penjelasan kepada masyarakat bahwa kenaikan BBM atau pertamax merupakan kebijakan yang wajar.Bisa dikatakan, kenaikan pertamax yang terjadi setiap dua pekan dipengaruhi oleh naik turunnya harga minyak 
dunia, dan hal tersebut adalah hal yang tak bisa dihindarkan. Penutur menyatakan tuturan tersebut tanpa maksud apa-apa.

\section{Tindak Ilokusi}

Tindak ilokusi adalah tindak melakukan sesuatu dengan maksud dan fungsi tertentu. Tindak ilokusi ini disebut juga The Act of Doing Something. Leech (1993) menyatakan bahwa ilokusi merupakan kategori yang menjadi pusat perhatian tindak tutur.

Tuturan ilokusi headline media online dapat digolongkan menjadi enam kelompok yakni tindak ajakan, tindak anjuran, tindak peringatan, tindak penolakan, tindak kritikan, dan tindak permintaan. Tindakilokusi ajakan merupakan tuturan yang mengajak mitra tutur untuk melakukan sesuatu.Terkait pemberitaan tentang issu kenaikan BBM, headline media online tidak banyak yang menggunakan strategi ilokusi ajakan.Hal ini disebabkan karena konten berita bersifat eksplanatif.Konten berita lebih bersifat penjelasan terkait polemik kenaikan bahan bakar dari sudut pandang jurnalis dalam menyikapi respon masyarakat atas kebijakan yang dikeluarkan oleh pemerintah.

Tindak anjuran memiliki maksud untuk menyampaikan usulan atau saran agar dilakukan. Namun, dalam tuturan ini lawan tutur memiliki kebebasan untuk menerima atau menolak maksud penutur. Tindak ilokusi bentuk anjuran pada headline media online terdapat dalam contoh berikut:

\section{Data (3) Agus: Anggota DPR Bebas Gunakan Hak Interpelasi Terkait BBM}

Penggunaan strategi ilokusi anjuran tampak pada data (3). Bahwa tuturan Agus: Anggota DPR Bebas Gunakan Hak Interpelasi Terkait BBM, diduga memiliki daya ilokusi bentuk anjuran. Strategi ilokusi anjuran terlihat pada pemarkah Bebas Gunakan. Agus sebagai bagian dari anggota DPR menganjurkan kepada seluruh anggota dewan untuk sepakat menggunakan hak politinya dalam menyikapi atau mngevaluasi kebijakan pemerintah terkait kenaikan BBM. Bentuk anjuran tak lain adalah menyarankan kepada lawan tutur untuk dilakukan. Agus menekankan bahwa adanya issu kebaikan BBM dari pemerintah, tidak serta merta sebagai wakil rakyat langsung secara frontal menolak kebijakan tersebut meskipun dengan dalih memperjuangan nasip rakyat kecil bumi 
Indonesia.Sikap tidak setuju terhadap kebijakan pemerintah bisa disampaikan secara elegan dengan memanfaatkan hak politik anggota dewan.

\section{Data (4) Penyesuaian Harga BBM Perlu Dilakukan Secepatnya}

Penyesuaian Harga BBM Perlu Dilakukan Secepatnya, diduga memiliki daya ilokusi bentuk anjuran yang tampak pada permarkah Perlu Dilakukan Secepatnya. Mengingat kembali bahwa bentuk anjuran merupakan usulan atau saran yang dikemukakan oleh penutur dengan tujuan saran atau usul tersebut segera dilaksanakan.Jurnalismendeskripsikan bahwa penutur dalam hal ini anggota DPR ingin menyampaikan usulan atau saran kepada lawan tutur dalam hal ini adalah pemerintah atau penentu kebijakan terkait kenaikan harga bahan bakar.Dilihat dari konteks tuturan tersebut penutur masih sebagai anggota DPR yang masih relevan dengan tuturan (3) terkait penggunaan hak interpelasi.Wujud dari hak interpelasi DPR yang disampaikan pada tuturan (3) terefleksi pada tuturan (4) bahwa anggota dewan mengusulkan kepada pemerintah supaya segera diadakan penyesuaian harga BBM.Penggunaan tuturan 'penyesuaian' harga bahan bakar memiliki makna memperhalus konotasiakan adanya kenaikan harga bahan bakar. Pemarkah 'penyesuaian' juga memiliki nilai rasa yang lebih santun apabila dibanding dengan kenaikan harga bahan bakar.

\section{Data (5) MUI: Pemerintah Sebaiknya Lindungi Masyarakat dari Fluktuasi Harga}

Tuturan (5), MUI: Pemerintah Sebaiknya Lindungi Masyarakat dari Fluktuasi Harga diduga mengandung daya ilokusi bentuk anjuran yang terrefleksi pada pemarkah 'pemerintah sebaiknya'. Konteks yang terdapat pada pemarkah 'pemerintah sebaiknya'merupakan bentuk anjuran penutur (MUI) kepada lawan tutur (pemerintah) terkait fluktuasi harga bahan bakar. Selaras dengan tuturan (4) bahwa DPR mengusulkan bahwa harga bahan bakar perlu disesuaikan. Mpenyesuaiakn tersebut dilakukan karena adanya fluktuasi harga atas kebijakan yang dikeluarkan pemerintah.Maka sebagai tindaklanjut, terbentuklah headline (5) bahwa ada lembaga nonpemerintah yang mengkritisi kebijakan pemerintah terkait fluktuasi harga bahan bakar.

Daya ilokusi lain bersifat permintaan diduga tampak pada duturan (6). Penanda ilokusi bersifat permintaan tak hanya menyampaikan sesuatu melainkan juga memiliki maksud 
untuk meminta terhadap sesuatu. Contoh tindak permintaan pada headline media online tampak pada tuturan berikut:

Data (6) DPD: Harga BBM Jangan Seperti 'Yoyo'.

1. Tuturan (6) DPD: Harga BBM Jangan Seperti 'Yoyo' diduga memiliki daya ilokusi bentuk permintaan tampak pada pemarkah Jangan Seperti 'Yoyo'. Konteks tuturan tersebut memiliki maksud mengharap kepada pembuat kebijakan (pemerintah) untuk tidak mempermainkan harga bahan bakar selayaknya mainan yoyo yang bisa dinaikturunkan sesuai selera pemain. Tuturan (6) tidak hanya tindak ilokusi bentuk permintaan tetapi juga untuk melakukan sesuatu. Tampak dari bahasa jurnalistik melalui DPD, meminta agar Harga BBM tidak naik turun karena dapat menyusahkan masyarakat. Permintaan tersebut tak lain agar pemerintah berkenan menunjau ulang kebijakan yang kontroversial tersebut.

Tindak peringatan merupakan teguran dalam memperingatkan sesuatu. Tindak ilokusi ini dimaksudkan untuk menghasilkann efek berupa tindakan oleh lawan tutur. Beberapa headline media online yang termasuk dalam tindak peringatan sebagai berikut:

\section{Data (7) Ahok: Angka Kemiskinan Naik karena BBM}

Tuturan (7) Ahok: Angka Kemiskinan Naik karena BBM diduga memiliki daya ilokusi bentuk peringatan. Daya ilokusi bentuk peringatan tampak pada pemarkah Angka kemiskinan naik karena BBM. Konteks tuturan dapat dipahami sebagai bentuk peringatan, bahwa penutur (Ahok) sebagai Gubernur DKI (2016) memberikan pernyataan yang bersifat peringatan kepada pemerintah atas akibat dari kenaikan BBM, maka angka kemiskinan naik. Sebagai seorang gubernur, Ahok sangat mengerti setiap permasalahan rakyatnya terutama terkait dengan ekonomi.Dampak negatif dari kenaikan harga bahan bakar adalah kenaikan semua kebutuhan pokok.

Oleh karena itu, secara langsung akibat kenaikan tersebut sangat mempengaruhi perekonomian masyarakat.Melalui tuturan (7), Ahok mencoba memberikan peringatan terhadap pemerintah (pembuat kebijakan kenaikan harga bahan bakar) bahwa kebijakan 
tersebut sangat memberatkan, tidak solutif dan berdampak pada kenaikan angka kemiskinan masyarakat Indonesia.

Daya ilokusi selanjutnya merupakan bentuk kritikan.Ilokusi bentuk kritikan merupakan tanggapan yang berupa kritik terhadap suatu hal atau peristiwa.Headline media online yang termasuk dalam tindak kritik tampak pada:

\section{Data (8) Kenaikan BBM Jadi Alasan Daya Beli Petani Rendah}

Tuturan (8) Kenaikan BBM Jadi Alasan Daya Beli Petani Rendah diduga memiliki daya ilokusi bentuk kritikan.Daya ilokusi bentuk kritikan tampak pada konteks tuturan tersebut.Masih terkait dengan isu kenaikan harga bahan bakar seperti pada tuturan-tuturan sebelumnya, pada tuturan (8) dapat dipahami sebagai bentuk kritikan terhadap pemerintah atas kenaikan harga bahan bakar.Kenaikan harga bahan bakar tidak hanya mempengaruhi perekonomian masyarakat saja dalam hal pemenuhan kebutuhan pokok seperti konteks yang terlihat pada tuturan (7).Kenaikan harga bahan bakar juga berdampak negatifbagi petani.Hal ini disebabkan karena dalam bekerja di sawah, petani banyak bergantung terhadap bahan bakar.Sebagian besar alat pertanian berbahan bakar bensin. Oleh karena itu, dengan kebijakan kenaikan harga bahan bakar secara langsung juga berdampak terhadap proses bertani para petani. Akibat harga bahan bakar naik, menyebabkan daya beli petani menjadi rendah.Akibat daya beli petani rendah, maka berakibat pada kelangkaan stok produk pertanian di pasar.Akibat kelangkaan produk pertanian di pasar, maka berpengaruh terhadap kenaikan harga produk pertanian.

Bentuk ilokusi selanjutnya adalah penolakan.Bentuk penolakan merupakan tuturan yang bersifat menyampaikan tampikan atau tolakan terhadap sesuatu. Tindak ilokusi bentuk penolakan tampak pada:

\section{Data (9) In Picture: Mahasiswa Makassar Demo Tolak Kenaikan BBM}

Tuturan (9) In Picture: Mahasiswa Makassar Demo Tolak Kenaikan BBMdiduga memiliki daya ilokusi bentuk penolakan yang tampak pada pemarkah 'tolak kenaikan $B B M^{\prime}$ '. Konteks tuturan di atas dapat dipahami sebagai bentuk penolakan yang jelas tampak pada bentuk verbalnya.Penolakan tersebut mengacu pada kebijakan kenaikan harga bahan bakar.Bentuk ketidaksetujuan atas kebijakan pemerintah terkait kenaikan 
harga bahan bakar, membuat mahasiswa di Makasar melakukan demonstrasi penolakan kenaikan harga bahan bakar.

\section{Perlokusi}

Tindak perlokusi merupakan tindak tutur yang pengutaraannya dimaksudkan untuk mempengaruhi lawan tutur. Efek atau daya pengaruh ini dapat secara sengaja atau tidak sengaja dikreasikan oleh penuturnya. Berikutheadline media online yang diduga memiliki tindak perlokusi:

\section{Data (10) Pembatalan Kenaikan BBM Diduga Hasil Instruksi Presiden Jokowi}

Tuturan (10) Pembatalan Kenaikan BBM Diduga Hasil Instruksi Presiden Jokowi diduga memiliki daya perlokusi. Perlokusi tampak pada konteks tuturan bahwa pembatalan kenaikan harga bahan bakar berdasarkan instruksi Presiden.Isu terkait kenaikan harga bahan bakar sudah santer terdengar bahkan menjadikan sebagian masyarakat meluapkan penolakan dengan unjuk rasa, tampak pada tuturan (9).Semua rasa geram, apatis terhadap pemerintah terutama penentu kebijakan atas kenaikan harga bahan bakar menjadi sirma setelah adanya pernyataan dari Presiden terkait pembatalan kenaikan harga bahan bakar.Karena disampaikan langsung oleh Presiden, maka rakyat secara spontan mempercayai atas pesan yang disampaikan Presiden.Penentu kebijakan terkait kenaikan harga bahan bakar ditentukan oleh instnasi pemerintah bukan oleh seorang presiden.Tetapi masyarakat secara langsung terpersuasi oleh tuturan Presiden.Akan berbeda apabila yang menyampaikan pesan pembatana kenaikan harga bahan bakar adalah menteri.Maka respon masyarakat tidak secara langsung terpersuasi.

\section{Simpulan}

Pengembangan strategi pragmatik dalam proses jurnalistik berpengaruh terhadap pencitraan atas tokoh yang diberitakan. Secara langsung atau tidak, pencitraan tokoh politik sampai public figure dipengaruhi oleh strategi pragmatik yang dikemas jurnalis dalam media berita.Tokoh politik sampai public figuresaling melakukan kolaborasi untuk 
menciptakan kesan yang menarik. Kesan menarik atau pencitraan positif akan mengubah konsep masyarakat atas penilaian semalama ini. Semakin tinggi jurnalis daya pragmatic yang dikembangkan jurnalis dalam menulis berita, maka akan semakin baik pula kualitas berita yang diberikan.

Sesuai dengan hasil penelitian strategi pragmatik pada Headline berita pada Republika.co.iddapat disimpulkan bahwa dalam penciptaan headlineberita sudah menerapkan strategi pragmatik. Strategi pragmatik yang dominan digunakan adalah strategi ilokusi. Strategi ilokusi menjadi dominan karena pembaca diharapkan meyakini, percaya, dan dapat mengembil sikap politik atau ekonomi terhadap konten berita yang menjadi headline media tersebut. Pemberitaan dikemas dengan strategi ilokusi oleh jurnalis dengan tujuan untuk menciptakan opini masyarakat dari tokoh-tokoh pilitik yang menjadi headline.

\section{Daftar Pustaka}

Leech, Goeffry. 1993. Prinsip-prinsip Pragmatik. (Terjemahan M.D.D Oka).Jakarta: Universitas Indonesia Press Yule, George. 1996. Pragmatics. Oxford: Oxford University Press.

Republika.co.id. diakses pada Januari - Juli 2017 